\title{
The Evolution of General Administrative Proceedings ${ }^{1}$
}

General administrative proceedings ${ }^{2}$ have a rich and interesting history in the twenty-five years of the Polish People's Republic. ${ }^{3}$ It is especially worth remembering as Poland has been a leader in the field of administrative proceedings for a long time. The point of departure for their postwar evolution was provided, as in many other branches of law, by the legal institutions developed in the twenty years of the interwar period.

The Decree of the President of the Republic ${ }^{4}$ of 22 March 1928 on Administrative Proceedings, similar to today's Code of Administrative Procedure $^{5}$, was not the only piece of legislation regulating administrative proceedings; however it was the principal legislation in this fielda codification of administrative proceedings (although it was not formally called this). The DPR was to a very large extent modelled on the 1925 Austrian procedure, the first ever code of administrative proceedings;

1 Translated from: Z. Janowicz, Rozwój ogólnego postępowania administracyjnego, "Ruch Prawniczy, Ekonomiczny i Socjologiczny” 1970, 3, pp. 121-139 by Tomasz Żebrowski and proofread by Stephen Dersley and Ryszard Reisner. Translation and proofreading was financed by the Ministry of Science and Higher Education under 848/2/P-DUN/2018. This is just a brief overview of the evolution of administrative proceedings after WWII. Its conciseness is also the reason behind relatively scarce references to the rich literature on the subject. In 1966, publications on the new codification of administrative proceedings numbered over 200 items; see J. Litwin, Bibliografia KPA, “GiAT” 1966, no. 4-10.

2 Hereinafter: administrative proceedings.

3 Hereinafter: PRL.

4 Hereinafter: DPR

5 Hereinafter: CAP. 
the DPR was practically its copy. The model was excellent and, moreover, it drew on many years of experience; in particular on the rich collection of decisions handed down by the Vienna Administrative Tribunal and the equally rich juristic literature. Besides Poland, the Austrian model was adopted by the countries that used to belong, if only in part, to the Austro-Hungarian Empire and felt the impact of Austrian law and juristic literature: Czechoslovakia (1928) and Yugoslavia (1930). ${ }^{6}$ Since that time, these countries led the world as regards the codification of administrative proceedings. The 1928 DPR remained in force for a long time after WWII — until the end of 1960. Interestingly, it remained in force without any formal amendment, which does not mean that it did not undergo certain indirect modifications under the conditions of the new political system, especially when the so-called complaint and grievance procedure was introduced.

The procedure, modelled on Soviet law, was introduced in 1950/51 as a broadly conceived means of supervising the decisions and other activity of state administration. Complaints and grievances could be filed by any citizen with any organ, regardless of its instance (even if directly to the supreme organ) in both one's own (individual) interest and that of another person, and in a community interest (actio popularis); filing of a complaint or a grievance was not restricted by any time limit.

The procedure of complaints and grievances, later sanctioned by the PRL Constitution of 22 July $1952^{8}$, undeniably played a positive role

6 M. Zimmermann in the collective handbook: M. Jaroszyński, M. Zimmermann, W. Brzeziński, Polskie prawo administracyjne. Część ogólna, Warszawa 1956, p. 361, points out that many old Austrian regulations were still in force in these countries at that time.

7 The Resolution of the Council of State and of the Council of Ministers of 14 December 1950 on considering and disposing of appeals, letters and complaints of people and press criticism, M.P. no. A-1 of 1951, item 1. The Executive Instruction issued by the Council of Ministers to this Resolution of 10 January 1951, M. P. no. A-2, item 16. Below, the term "complaints and grievances" shall be used for short, which is almost universally used in the literature and practice. Moreover, “complaints and grievances” are expressly mentioned in the Constitution of the Polish People's Republic, Article 73.

8 Article 5(2) and Article 73. 
in strengthening the supervision of administration (covering the law, including internal self-imposed rules of administration and actual activities) by the population at large. It affected administrative proceedings as such by enabling (together with the legislation on people's councils) to set aside some decisions of departments. This could be done as a form of supervision by "horizontally" superior organs, i.e. council presidia, or by deactivating certain procedural institutions such as information and submission (so-called "imperfect" remedies) as well as referring a case to a higher instance. ${ }^{9}$

However, the procedure had certain, even serious shortcomings. For one, a major error lay at the inception of the procedure of complaints and grievances; it was not brought into line with the rules for administrative proceedings then in force. Actually, it was introduced as if the rules did not exist at all (this can be seen, as a matter of fact, in the very form of the relevant acts: resolutions and an instruction).$^{10}$ Hence, a bizarre and difficult situation arose in practice, namely a duality of proceedings (administrative proceedings in the strict sense, and "complaint” proceedings) and an unlimited right to file complaints and grievances with all organs (as a matter of fact not only state ones) regardless of their instance. The situation undermined the permanence of administrative decisions and thus lowered the reliability of legal transactions, leading to breaches of legality. Of course, the efficiency of administration suffered, too.

Moreover, the early 1950s witnessed extensive personnel changes in the civil service, related to the reform of people's councils (the foundation of the local organs of unitary State authority, the abolishment of the so-called general administration authorities and self-government authorities) ${ }^{11}$ New civil servants, including also the personnel of first-tier local organs_council presidia—often were not familiar with

9 Cf. M. Zimmermann, op.cit., pp. 329, 381, 388, 394.

10 Cf. ibidem.

11 Act of 20 March 1950 on Local Organs of Unitary State Authority Journal of Laws, no. 14, item 130. 
administrative proceedings or knew little about them. At the same time, there appeared (especially in practice) views questioning the usability or even the validity of the 1928 DPR, because of its provenance from a different political system. In these circumstances, provisions on administrative proceedings were often not applied and less complex (and hence more “available”) “complaint” proceedings were settled for.

The raising of the status of administrative proceedings commenced in 1956-1957, with a new People's Council Act being enacted on 25 January 1958. Article 55 of this Act, ${ }^{12}$ providing for the possibility, by way of supervision, of setting aside or reversing any decision made by a department head, stipulated unambiguously that "if, however, the decision made by a department head granted any right to an individually specified person(s), the presidium may set aside the decision by way of supervision only in cases provided for in administrative proceedings or separate statutes”. There appeared suggestions to draft a new codification of administrative proceedings that would-besides the procedure of complaints and grievances - take into account other new institutions of the socialist State such as, in particular, the structure of people's council presidia and departments, founded on the principle of dual subordination, and supervision by public prosecutors. The new codification was also expected to ensure that social organisations could take part in proceedings, etc. A preliminary draft of the code was submitted by the Association of Polish Lawyers. In January 1958, the President of the Council of Ministers appointed a commission to draft provisions on administrative proceedings. ${ }^{13}$ At almost the same time-and this is worth stressing — extensive work was begun on systematizing administrative legislation. ${ }^{14}$

12 Consolidated text: Journal of Laws no. 29 of 1963, item 172.

13 Disposition by the President of Council Ministers of 28 January 1958. For more information v. S. Rozmaryn, O projekcie kodeksu postępowania administracyjnego, "Państwo i Prawo" 1959, vol. 4, p. 629, who assigns the commission composition and course of work. The draft was presented by Prof. E. Iserzon and Prof. J. Starościak.

14 The Central Commission for the Systematisation of Administrative Legislation was appointed by Disposition no. 114 of the President of the Council of Ministers of 11 June 1958. Drafted by the Commission, the plan of its work was approved by the Resolution of 
The new codification was underpinned by the conviction that "only honest bilateral cooperation between the authorities and citizens as well as citizens and the authorities is the best guarantee that proper social conditions will develop and socialist legality will thrive". ${ }^{15}$

The Code was very carefully drafted as result of over two years of work by the Commission. ${ }^{16}$ The drafters could take advantage of the vast experience accumulated when the 1928 DPR was in force: older (prior to 1939, including the decisions of the Supreme Administrative Tribunal) and newer (especially after the procedure of complaints and grievances was introduced and the reform of local administration was carried out), the extensive Polish literature on the subject and comparative law information ${ }^{17}$ such as new legislative solutions adopted by some socialist countries (Yugoslavia, Czechoslovakia, Hungary). A lot of valuable information was gathered as a result of a broad public discussion of the bill. ${ }^{18}$ No inconsiderable contribution to the bill was made by the Sejm's Internal Affairs Committee, either. ${ }^{19}$

the Council of Ministers no. 421 of 15 October 1959. For more information v. Statement by the Chairman of the Central Commission for the Systematisation of Administrative Legislation, Rada Narodowa, 1959, no. 45, p. 5.

15 From the speech by a deputy, M. Żurawski, delivering the report of the Internal Affairs Committee on the cabinet bill-Code of Administrative Procedure at the session of the Sejm on 14 June 1960. (Shorthand Report of the 46th session of the Sejm on 14 June 1960. Warszawa 1960, PRL Sejm, 2nd term, 7th session, p. 7, col. 1).

16 Just how very intensive the work of the Commission was can be seen from the fact that in a relatively short time for drafting a codification, eight draft bills were drawn up. Extensive information on the work of the Commission is given by S. Rozmaryn, O projekcie kodeksu postępowania administracyjnego..., op.cit., p. 629 ff. and W. Dawidowicz, Ogólne postępowanie administracyjne. Zarys systemu, Warszawa 1962, pp. $17 \mathrm{ff}$.

17 S. Rozmaryn says "Le c.p.a. a été préparé sur la base des vastes matériaux de droit comparé, entre autres français”. S. Rozmaryn, Principes généraux de la procedure administrative en Pologne, "Deuxièmes Journées Juridiques Polono-Françaises” 1951.

18 The fifth draft of the bill was subjected to discussion after it was published in 1959 . The wording of the bill amended after the discussion is the subject of S. Rozmaryn, Projekt kodeksu postępowania administracyjnego - w nowej postaci”, "Państwo i Prawo” 1960, vol. 4-5, pp. $609 \mathrm{ff}$.

$19 \mathrm{~V}$. the quoted speech by the deputy-rapporteur M. Żurawski delivering the report of the Commission in the Sejm. 
The code adopted by the Sejm on 14 June 1960 is - in the words of Franciszek Longchamps- “a work of mature political prudence and high legal culture”. It undoubtedly ranks among the most important legislation defining the relations between state organs and citizens and their organisations (professional, self-government, cooperative and others). What is more, it paves the way for the requisite relations to take proper shape not only in the domain of law, but also politics (cf. certain general principles).

\section{II}

What then are the principal characteristics of the new codification and what is its role in the evolution of administrative proceedings in Poland?

1. The Code covers two separate proceedings: administrative proceedings in the strict sense and the so-called "complaint" proceedings. ${ }^{20}$ The former aims at issuing a decision granting certain rights (e.g. a decision to allot a flat, industrial license, water permit) or imposing certain responsibilities (e.g. an order to demolish a house in imminent danger of collapse, a decision to recognise a natural object as a nature monument). In the course of proceedings, a party enjoys specific rights, as for instance the right to present evidence, inspect files and pursue remedies (appeals, complaints, etc.). These proceedings resemble judicial (civil) proceedings; they are sometimes called jurisdictional proceedings. ${ }^{21}$ However, the purpose of the "complaint" proceedings ${ }^{22}$ is not the issuing of a decision (albeit they may many a time lead to the reversal or

20 This term is not used in the Code, but is widely used in the relevant literature.

21 V. M. Zimmermann, Z rozważań nad postępowaniem jurysdykcyjnym i pojęciem strony $w$ kodeksie postępowania administracyjnego in: Księga pamiq̨tkowa ku czci prof. dr K. Stefki, Wrocław 1967, pp. $433 \mathrm{ff}$.

22 It is well known that a complaint may be filed not only by every citizen, but also by a professional, self-government, cooperative and other organisation. As complaints are to be considered and investigated the press articles and notices and other items of news having the nature of a complaint that have been sent by editorial offices to the competent organ CAP, Article 177. 
setting aside of a decision); their purpose is rather to draw the attention of superior organs to the failure of inferior organs to carry out their tasks properly (breaches of law, neglect, procrastination, a negative attitude to the people who want to have their case heard, etc.), i.e. it is about initiating supervision. A competent body is obliged to investigate a complaint and give an answer to the complainant within a specified time limit. In certain cases, these two separate types of proceedings "meet", for instance when administrative proceedings are pending (e.g. for granting a license) and one of the parties takes advantage of the right enjoyed by every citizen to file a complaint. The Code, abolishing the former duality in such situations, stipulates that complaining about a decision is tantamount to filing an appeal. Thus, no two separate proceedings run concurrently: the "complaint" proceedings morph into administrative ones (a "transformation" of the complaint and complaint proceedings takes place). “Complaint” proceedings have thus become an institution supplementing administrative proceedings and not competing with them with respect to matters that are (or may be) settled by a decision. In the "complaint" proceedings" themselves, a rule has been laid down that complaints are to be filed with the competent bodies. Thereby a defect has been removed that caused a lot of trouble in the pre-Code times.

2. The Code regulates administrative proceedings not only before state administration bodies and bodies of state administration units, but also before the bodies of professional, self-government, cooperative organisations and other social organisations when by operation of law they are given the authority to deal with individual cases coming within the purview of state administration (e.g. the Bar Council admitting to the Bar or disbarring advocates and trainee-advocates). The organs of the named organisations are treated then on an equal footing with state administration organs.

In agreement with the principles of the political system of the socialist State, the Code provides for the possibility of admitting a social organisation, granted the status of a party, to participate in proceedings 
involving another person "if such participation is justified by the constitutional objectives of the organisation, and the interest of the community calls for it” (Article 28); a social organisation, pursuing its constitutional objectives, takes on the capacity of a spokesman for the social interest (even a broader right of participation was granted to social organisations in the new civil-court proceedings). ${ }^{23}$

3. Another novelty in our administrative proceedings, the provision for the participation of a public prosecutor ${ }^{24}$ that grants him/her (a) the right to address a motion to the competent organ of state administration to institute proceedings for the removal of non-conformance with the law (the public prosecutor may act in this case on his own initiative or follow up a complaint by the citizen who feels aggrieved), (b) the right to participate in any stage of administrative proceedings to ensure that the proceedings themselves and the decision reached are lawful; public prosecutors notify the body in question about their taking the place of a party in proceedings and since then they are their participant (i.e. their participation in proceedings does not depend, as is the case with a social organisation, on the will of an organ); (c) the right to file an opposition in the cases provided for in the Code (Articles 127, 137, 141) or elsewhere after proceedings end, that is, after a final decision is issued. Public prosecutors enjoy all the rights of a party to proceedings and, on top of that, they may pursue the extraordinary remedy of opposition. This extraordinary remedy is enjoyed by a public prosecutor not only in the same cases as it is by party: they are slightly privileged as well. The organ with which the opposition was filed has to consider it forthwith and determine if it is necessary to postpone a decision until the opposition is dealt with. The code has extended the general supervision by the public prosecutor"s office to cover partially decisions issued

23 Cf. CAP, Articles 3 and 61-63.

24 The participation of a public prosecutor in administrative proceedings—albeit in a much narrower scope - was already known earlier. Cf. Regulation by the General Public Prosecutor of 19 June 1957 based on the very general provisions of the Public Prosecutor's Office Act of 20 July 1950. 
by the supreme authorities of State administration (approach procedure, Article 150).

The solutions adopted in the Code were not only taken over later by the new 1967 Public Prosecutor"s Office Act, ${ }^{25}$ but also extended to other types of proceedings. ${ }^{26}$

4. One of the most characteristic traits of our new codification, and as a matter of fact of the codifications of some other socialist countries (Yugoslavia, Czechoslovakia), ${ }^{27}$ is the setting out of the general principles of administrative proceedings. What is meant here is certain general (fundamental, central) rules of procedure considered as such by the legislator and set out in Chapter I of the Code (Articles 4-12). ${ }^{28}$ When compared with the other codifications, the Polish legislator has worded the general principles in the most exhaustive manner. ${ }^{29}$

These are the following principles: legality (Articles 4 \& 5; some authors additionally distinguish the principle of lawfulness), the administration bodies taking into account, on their own motion, the state and social interest and the reasonable interest of citizens (Article 4 \& 5), searching for the objective truth (Article 5), active participation of the

25 Act of 14 April 1967 on PRL Public Prosecutor's Office, Journal of Laws, no. 13, item 55).

26 V. Article 44 ff. of the Act of 14 April 1967 on PRL Public Prosecutor's Office.

27 The Yugoslav codification of 1953 (consolidated text, 1965) and Czechoslovakian of 1960 (and later of 1967); quoted after J. Starościak, Wprowadzenie do prawa administracyjnego europejskich państw socjalistycznych, Warszawa 1968, p. 237. Whereas the Hungarian codification of 1957 took a different stance, v. J. Martonyi, La protection du citoyen dans les procédures administratives, Szeged 1968, p. 6, which says: Les dispositions de la loi hongroise sur les règles générales de la procédure administrative reposent sur les principes généraux régissant toute codification socialiste de la procédure administrative. Sans être énumérés comme dans les codes de procédure administrative de la Pologne, de la Tchécoslovaquie et de la Yougoslavie, ces principes ressortissent plus ou moins directement soit des dispositions de la loi, ou de l'exposé des motifs qui l"accompagne. V. p. 7 ff.

28 Articles 1-3, which were included in Chapter I, General Principles, do not lay down any fundamental rules of procedure but concern (together with some final provisions, in particular Article 194) only the scope of application of the Code. This drafting inaccuracy is a source of misunderstandings.

29 "While the first prize for the legal drafting of the general principles of administrative proceedings goes to the Yugoslav codification of 1953, the most exhaustive wording of the principles has been offered by the 1960 Polish codification of administrative law in its introductory provisions”. J. Starościak, Wprowadzenie do prawa administracyjnego..., op.cit., p. 238. 
parties in proceedings (Article 8), boosting the confidence of citizens in state organs (Article 6), providing legal aid to parties (Article 7), persuading parties (Article 9), quickness and simplicity (Article 10), conducting proceedings in writing (Article 11), and the permanence of final decisions (Article 12).$^{30}$ Some of these principles were known to the former administrative proceedings, with the Code modifying them to a higher or lesser degree and expressing them as a rule more forcefully (and, of course, isolating and giving them the status of general principles). A more forceful wording, for example, was given, to the principles of audi et alteram partem and permanence of final decisions (they were hedged with sanctions, too-Articles 127(1)(4) \& 137(1)(3)); the impact of judicial proceedings can be easily discerned here. Today, a different political tenor is shared by the principle administrative bodies taking into account, on their own motion, the state and social interest and the reasonable interest of citizens, etc. ${ }^{31}$ Instead of the orality of proceedings prevailing previously, conducting proceedings in writing is now the rule.

Some principles are a complete novelty and it is they that merit greater attention. Article 7 of the CAP states that "state administration

30 In the relevant literature, these principles are somewhat differently classified. Cf. S. Rozmaryn, O zasadach ogólnych kodeksu postępowania administracyjnego, "Państwo i Prawo” 1961, vol. 12, pp. 890 ff.; E. Iserzon in: Kodeks postępowania administracyjnego. Komentarz, teksty, wzory i formularze, eds E. Iserzon, J. Starościak, 3rd ed., Warszawa 1965, pp. 24 ff.; E. Iserzon, Prawo administracyjne. Podstawowe instytucje, Warszawa 1968, p. 213; W. Dawidowicz, Ogólne postępowanie administracyjne..., pp. 101 ff., M. Zimmermann, Institutions fondamentales du code de procedure administrative polonaise loi $d u$ 14 juin 1960, “Études sur le droit polonais actuel”, Paris-La Haye 1968, pp. 69 ff.

31 This principle is laid down in Article 4 ("State administration organs shall act pursuant to the law, being guided by the interest of working people and objectives related to the building of socialism") and Article 5 ("In the course of proceedings, state administrative organs shall guard people"s legality and shall take any necessary steps to establish facts in the case scrupulously and to dispose of it, having in mind the social interest and the reasonable interest of citizens"). S. Rozmaryn, who sees in Article 4 the principle of teleology, says that this principle "may never give a pretext to breach the law. The CAP does not sanction any exceptions to the principle of legality, nor does it permit any "deviations" from, or relaxations of, this principle in the name of teleology". S. Rozmaryn, O zasadach ogólnych kodeksu postępowania administracyjnego..., op.cit., p. 891. 
bodies, in the course of proceedings, shall take care that the parties are not harmed by their ignorance of the law and for this purpose the organs shall give the parties all necessary explanations and guidance”. This principle, referred to above as the principle of giving legal aid to parties, departs significantly but favourably from the old legal maxim ignorantia iuris nocet that usually applies. A similar departure-albeit not so distinct - was made in the new Code of Civil Procedure several years later. ${ }^{32}$ The principle of legal aid no doubt seeks to put a party on a par with the organ as far as possible.

The principle of persuasion makes state administration bodies explain to the parties "the legitimacy of the reasons that the organs are guided by when disposing of the case so that, as far as possible, they make the parties abide by the decision without the need to resort to coercion". Specifically, the principle of persuasion requires that decisions be justified as carefully and exhaustively as possible in respect of the law and facts, and that their expediency or even social necessity (as for instance with the so-called expropriation of a right, Article 141) be indicated.

Under the principle laid down in Article 6: "State administration bodies should conduct proceedings in such a way so as to boost the confidence of citizens in the organs of the State”. Stefan Rozmaryn maintains that:

The provision of Article 6 is actually the kingpin that holds together all the general principles of procedure. For this is the principle of the broadest scope and the greatest political impact. The Code makes the political assumption that the strength of the State and the efficiency of its operations turn on the confidence of citizens in the state authority. Given that

32 Cf. especially the CCP, Articles 5 and 212. For more information v. W. Siedlecki in the commentary to the code of civil procedure. W. Siedlecki, Kodeks postępowania cywilnego. Komentarz, Warszawa 1969, pp. 88, $384 \mathrm{ff}$. A different approach is found in employee claim actions: Article 460(1). V. also the decision of the Supreme Court of 20 January 1966 and comments by Z. Resich. 
it is the administration bodies that are the venue where the state authority meets the citizen in proceedings in a myriad of cases every day, their judicious operation vis-à-vis citizens may bring a great political advantage. Conversely, if the operation is not up to the mark (bureaucratic, repulsive, unfair, etc.), it may cause a lot of political damage. The above principle, therefore, is even broader than a mere warning against red tape. ${ }^{33}$

These comments - as a matter of fact by one of the Code drafters - hit the nail on the head. Specific proceedings before an administration body may take their correct formal course, i.e. in compliance with the law. If, however, they take place in an atmosphere that is unfavourable (or impolite) for a party, their social impact will be negative. ${ }^{34}$

All the principles listed above are, in agreement with the will of the legislator, general and fundamental to the entire administrative proceedings. Their catalogue, again at the legislator's behest, is closed. However, the juristic literature records an attempt to extract "fundamental principles" and "auxiliary principles" from the general principles catalogued in the Code and from its further provisions. Such an attempt was made by J. Starościak in the well-known handbook of administrative law. ${ }^{35}$ He believes that "the general principles laid down in the introductory provisions of the CAP may not be identified with the full list of the CAP's fundamental principles". ${ }^{36}$ It is quite obvious that the road to juristic classifications is always wide open and that it is arguable whether the catalogue of the fundamental principles of administrative proceed-

33 S. Rozmaryn, O zasadach ogólnych kodeksu postępowania administracyjnego..., op.cit., p. 903.

34 Politeness in dealing with cases is also de rigueur pursuant to the Act of 17 February 1922 on State Civil Service, Journal of Laws no. 11 of 1949, item 72; Article 25, and our latest official practice: the Act of 15 July 1968 on People's Council Officials, Journal of Laws no. 25, item 164; Article 5, in particular subparagraphs 8 and 14.

35 J. Starościak, Prawo administracyjne, Warszawa 1969, pp. 261 ff. The same attempt, as a matter of fact, had been made in an earlier handbook published together with E. Iserzon. Due to the nature of this article, it is hardly possible to offer any longer polemic, hence, only a few comments shall be given.

36 Ibidem, p. 263. 
ings, contained in Articles 4-12, could be supplemented with others deduced from the detailed provisions of the CAP. One such additional fundamental principle could be that of two-instance proceedings (which, by the way, Starościak counts among auxiliary principles). However, not only the will of the legislator argues in favour of considering all the general principles laid down in Articles 4-12 as fundamental - so does the analysis of their legal content. For instance, the principle of permanence of final decisions, fundamental, after all, to any (not only administrative) trial, can hardly be considered auxiliary. ${ }^{37}$

All the CAP general principles are legal norms, and not mere declarations or guidelines, which is emphasized strongly in the relevant literature. Taking these principles to be legal norms gives rise to a number of inconsistencies. In particular, the breach of a principle must be treated as any breach of the law, with all its consequences. Proving such a breach is relatively simple when a general principle has been expressly implemented by relevant detailed provisions (as is the case, for instance, with the principles of objective truth, quickness and simplicity, the active participation of parties, and others). Difficulties may arise when it is alleged that the principle which has been breached is rather inconcrete, such as, in particular, the principle of enhancing citizens' trust in state organs. It would not be an easy task for a party to prove that, for instance, the impolite and unkind attitude taken by an official in a state administration body has adversely affected-despite adhering to any and all procedures - the manner in which the case was dealt with. This is where judicial decisions could greatly help: in the absence of general administrative judiciary the task falls to supreme state administration bodies and the Council of Ministers Office.

In this context, a significant question arises. Is the applicability of the general provisions limited to matters regulated by the CAP? Pointing to separate administrative proceedings ("excluded proceedings" in the

37 Ibidem, p. 265. 
CAP, Article 194, for instance, tax, disciplinary and other proceedings), Rozmaryn had already claimed long ago that

\begin{abstract}
although administrative proceedings in these matters are not regulated by the CAP, [...] the general principles may and should be by analogy applied in an auxiliary capacity to the "excluded" matters. This is especially true for cases where the excluded proceedings lack the proper regulation of specific matters. Moreover, the CAP general principles may serve as interpretation guidelines in the excluded matters, too. ${ }^{38}$
\end{abstract}

Longchamps went even further, by claiming that:

Since we do not have general provisions of administrative law (as there are, for instance, in civil law), it can be claimed that Chapter I contains general principles whose significance is not necessarily limited to purely procedural matters. Actually, they may be more broadly applied to our today"s administrative law, specifically, to the interpretation and assessment of particular legal situations. ${ }^{39}$

The general principles must of course be applied first and foremost wherever statutes (or other normative acts) expressly provide for the application of the CAP as appropriate. For example, Article 17 of the Act of 17 June 1966 on Executive Proceedings ${ }^{40}$ states: "Unless the provisions hereof provide otherwise, the provisions of the Code of Administrative Proceedings shall apply as appropriate to executive proceedings”.

At this juncture, note must be taken of a very interesting case of the impact of the CAP general principles on our recent administrative legislation, and in the "non-procedural" sphere, for that matter. The Act of 15 July 1968 on People”s Council Officials sets out their major respon-

38 A different stance is taken by J. Jendrośka, Zakres obowiq̨zywania k.p.a. w postępowaniach szczególnych, “GiAT” 1967, no. 2, p. 42.

39 F. Longchamps, Problem trwałości decyzji administracyjnej..., p. 911.

40 Journal of Laws, no. 24, item 151. 
sibilities, clearly following the model of the CAP general principles. Under Article 5 of the Act:

[...] official is obliged to: [...] (8) act thoroughly, quickly, impartially, and in a manner boosting the confidence of citizens in the organs of people"s power, making use of possibly simple means to dispose of the case properly, ${ }^{41}$ (9) give necessary help with the settling of cases to citizens, ${ }^{42}(10)$ take care that the citizen is not harmed by his ignorance of the law, provide necessary information and explain the principal objectives and policies of people"s power [... ${ }^{43}$

(5) The CAP administrative proceedings are another step in the direction of bringing this type of proceedings closer to a court trial. As a matter of fact, this follows the general line of evolution of administrative proceedings in many countries (and not only those with old codification traditions). ${ }^{44}$ The degree of convergence is toute proportion gardée rather high. The reason why administrative proceedings were fashioned in the CAP in this manner was the desire to strengthen legality. The desire was particularly strong after certain negative experience related to the protection of the rights and interests of citizens prior to 1956. In addition, it was no doubt strengthened by the absence of a comprehensive judicial review of the administration.

41 Cf. CAP, Articles 6 and 10.

42 The formulation of the duty to give help is even broader here, as it seems, than in CAP, Article 7.

43 Cf. CAP, Article 7, and Article 8(4) of the Act of 25 January 1958 on People’s Councils, Journal of Laws no. 29/1963, item 172.

44 Possibly the most characteristic of this development line is the evolution of administrative proceedings in England and the United States of America (Federal Administrative Procedure Act of 11 June 1946) and in Scandinavian countries. For more information v. J. S. Langrod, Uwagi o kodyfikacji postępowania administracyjnego w niektórych państwach, "Państwo i Prawo" 1959, vol. 5-6, pp. 908 ff.; Moc obowiq̨zujq̨ca aktu administracyjnego i domniemanie jego ważności, “RPEiS” 1965, vol. 1, pp. 51 ff. and E. Iserzon, Prawo administracyjne..., p. 210. 
The problem of the considerable "judicialization" of administrative proceedings was raised in discussions on the draft code by pointing to its obvious advantages, but certain shortcomings of this option were not ignored either. The shortcomings are in fact slight: the introduction of certain new trial institutions or the expansion of existing ones entails sometimes a greater formalisation of proceedings (still, however, incomparably lower than that of a court trial). However, Dawidowicz was right to observe on a different occasion:

The more developed procedural provisions in a given system of administrative law are, the less leeway and randomness there is in the operation of individual state administration organs or their officials, the more efficient administration is and the better protection is ensured to the rights and interests of citizens. ${ }^{45}$

Better protection of the rights and interests of citizens in proceedings is ensured today by the broader definition of the concept of a party (which provides grounds for adopting the "subjective version" of this concept, similar to the concept of a party in a civil action) ${ }^{46}$, and by the enhancement of impartiality (significant expansion of provisions on the recusation of officials; entirely new provisions on a challenge to an organ), the granting of broader rights to a party in the course of explanatory proceedings (e.g. when it comes to the disclosure of the case file), and especially in the course of examining evidence (the right to participate actively in the proving of allegations; the adoption of the rule that a fact may be considered proven, provided that a party has had an opportunity to comment on the evidence introduced), new

45 The role of codification of administrative procedure. Theses mimeographed for the symposium on administrative procedure organised by the Legal Studies Committee, Polish Academy of Sciences, Warszawa, 4-6 September 1961. See also Janowicz's report from this symposium, "RPEiS” 1961, vol. 4, p. 329.

46 The concept of a party is possibly the most controversial issue in our administrative proceedings. A review of the literature on this matter is given in M. Zimmermann, Z rozważań nad postępowaniem jurysdykcyjnym..., op.cit., pp. 434 ff. 
provisions on interlocutory decisions and complaints, a favourable amendment of provisions on instituting proceedings de novo (obligatory institution de novo, adding to the catalogue of reasons for instituting proceedings de novo), etc. All these novelties are modelled to a lesser or greater degree on a court trial. ${ }^{47}$

A complete comparison of a court trial and administrative proceedings is hardly possible, for obvious reasons, but the "crucial idea of administrative proceedings - the active participation of a party in the proceedings, specifically, its cooperation in the making of the findings of fact and law in a case-is consistent with the key idea of a court trial” (Iserzon). ${ }^{48}$ After all, the goals and tasks of the judiciary and administration do differ, as do, consequently, their structure and modi operandi. For example, administration bodies are as a rule connected with one another by the relationship of hierarchy or supervision, which entails the possibility, which is not available to the judiciary, of setting aside a decision as a form of supervision. It is characteristic of administration — unlike the judiciary — to be able to institute proceedings the motion of an organ. Finally, the position of an organ in administrative proceedings is very different and peculiar: it is also a judge "in its own cause". ${ }^{49}$ Therefore, it cannot be expected that administrative proceedings become like a court trial in almost all aspects. Nonetheless, the point is, and the Code is clear about this, to ensure to the citizen or other party due process of law and consequently-if

47 The CAP has not acquiesced to the demands that administrative proceedings "resemble as much as possible" a court trial. Hence, the proposals to "legislate a formal interlocutory decision of instituting proceedings or a formal act of presenting collected evidence to a party prior to the issuing of a decision” etc. have been rejected; S. Rozmaryn, O projekcie kodeksu postępowania administracyjnego..., p. 638.

48 E. Iserzon, Prawo administracyjne..., p. 209.

49 Cf. E. Iserzon, Prawo administracyjne..., p. 209; F. Longchamps, O pojęciu stosunku procesowego między organem państwa a jednostkq, Księga pamiq̨tkowa dla uczczenia pracy naukowej K. Przybyłowskiego, Kraków- Warszawa 1964; J. Filipek, Stosunek administracyjno-prawny, “Zeszyty Naukowe Uniwersytetu Jagiellońskiego, Prace prawnicze” 1964, vol. 34, p. 155 ff.; J. Starościak, Prawo administracyjne, op.cit., p. 17. 
this is at all possible - to make the relationship between the organ and party one of "equality of arms". ${ }^{50}$

A fact which deserves separate mention is that Poland ranks among the countries that have for a long time attached much importance to administrative proceedings (even when administrative judiciary existed). There were no hesitations in calling them a trial; ${ }^{51}$ this stance finds even more support under the rule of the CAP. To this very day, in some legal systems (e.g. Italy, West Germany), as a rule the term "administrative trial” is avoided when referring to proceedings that take place before administration bodies. It is believed that a "trial" takes place only before a court (processo, Prozess), while only "proceedings" take place before administrative bodies (procedimento amministrativo, Verwaltungsverfahren). ${ }^{52}$

50 E. Iserzon devotes much attention to "equality of arms" in administrative proceedings. E. Iserzon, Prawo administracyjne..., op.cit., pp. $230 \mathrm{ff}$.

51 As early as in 1947, J.S. Langrod wrote in the foreword to the quoted commentary by J. Pokrzywnicki, Postępowanie administracyjne, Warszawa 1948, p. V: “To stop treating administrative proceedings as some kit of purely technical instruments, left basically to the good will of administrators, and instead to probe the logical consequences of conceiving of them as a "trial relation", i.e. without any logical gap between them and a court trial (e.g. before an administrative, civil or criminal court, etc.), is of the utmost importance. When in 1911, Fierich juxtaposed "administrative road" with the "road of law" (court trial), he approached the question in a manner that today seems completely antiquated and downright wrong. When today, in turn, reasonable suggestions emerge to treat the entire trial as a single whole, as a family, so to speak-admittedly branching out and diversified, but a whole nonetheless - we are exposed to a set of concepts that may shed some new light onto jurisprudential systematics and indirectly into legal life as well. V. also J.S. Langrod, Uwagi o kodyfikacji postępowania administracyjnego w niektórych państwach..., pp. $893 \mathrm{ff}$.

52 F. Becker writes: "Wie ein Teil der spanischen, so versucht auch die italienische Verwaltungsrechtsliteratur, einen Wesen unterschied zwischen dem Verwaltungsverfahren (procedimento amministrativo) und dem gerichtlichen Prozess (processo) zu finden. Dieser besteht nach der Lehre Benvenutis darin, dass das Verwaltungsverfahren der Interessenbefriedigung des Urhebers des Verwaltungsaktes und nicht der Parteien dient. Aus dieser Begriffsbestimmung folge, dass das Beschwerde- und das Disziplinarverfahren Prozessdisziplinen und nicht ein "mere procedimento" seien, da in ihnen das Interesse des Beschwerdeführers bzw. des disziplinarisch verfolgten Beamten grösser sei als das der Verwaltung”. F. Becker, Das allgemeine Verwaltungsverfahren in Theorie und Gesetzgebung - Eine rechtsvergleichende Untersuchung, Stuttgart-Bruxelles, 1960, p. 99. As far as the Federal Republic of Germany is concerned v. F. Becker, op.cit., pp. 130 ff. and Z. Janowicz, 
The 1960 codification has been highly commended both at home and abroad. ${ }^{53}$ What attracts praise above all is its, advantages such as the skilful inclusion in the system of administrative proceedings (or even the organic incorporation into the system) of three new legal institutions: "complaint" proceedings, the participation of a public prosecutor and the participation of a social organisation that has been granted the status of a party. Other advantages deserving praise include the formulation (and expansion when compared to cognate codifications) of general principles and ensuring due process of law to parties, which of course entails a more detailed definition of the rights and duties of an organ in proceedings than before.

Equally indisputable, as shown by already nine years of practice, is the enormous significance of the Code for the development of proper relationships between the state administration and citizens, social organisations and state organisational units. The Code has helped tremendously to develop the proper "working style" of administration bodies and improve the "administration culture". These highest accolades are not diminished - in the belief of the present author-by various and quite frequent shortcomings, and mistakes in the application of the Code. ${ }^{54}$ These are in fact rather rare and stem from the provisions of the Code

Tendencje rozwojowe ustroju administracyjnego Niemieckiej Republiki Federalnej, Poznań 1969, pp. $160 \mathrm{ff}$.

53 For foreign opinions on the Code v. A. S. Angełow, Administratiwnoto proizwodstwo w Czechosłowakia, Ungaria i Polsza, Sofia 1962, p. 96; F. Becker, op. cit., who discusses a CAP draft; W. Gellhorn, Protecting citizens against administrators in Poland, "Revue internationale des sciences administratives” 1964, no. 7, G. Langrod, La codification de la procédure administrative non contentieuse en Pologne, "La Revue administrative”, 1960, no. 6; W. Meder, Die Verwaltungsverfahrensordnung der Volksrepublik Polen, "Verwaltungsarchiv" 1961, Heft 4.

54 They were spoken of in the course of a very interesting discussion held under the title The CAP in practice, "GiAT" 1965, no. 5, pp. 4 ff; Wendel, Executive Director of the Office of Council of Ministers said that CAP detailed provisions "are applied with lesser or greater accuracy, but the "spirit of CAP" enshrined in its general principles, still "does not hover" freely over our offices” (p. 17). Since then, however, the application of CAP has witnessed some changes for the better; this a result of improving professional skills of administration officials. 
themselves (there is still a shortage of trained officials, substantive administrative legislation has not been fully systematised yet, and there is an excess of “departmental legislation”, etc.).

Any new codification precipitates a wave of judicial decisions and publications, which in the case of the 1960 codification of administrative procedure deserves a special mention. Already in statu nascendi, the Code provoked a great surge in pertinent literature and the general public's increased interest in administrative procedure. The broad, lively and very fruitful public discussion is a convincing proof of this. The literature on the Code numbers now several hundred publications, ${ }^{55}$ written by academics, public prosecutors ${ }^{56}$ and quite a few administration practitioners. ${ }^{57}$ Of particular interest are the increasingly accessible decisions of supreme state administration bodies, which stimulate the relevant literature and vice versa-draw a lot from it.

As in any statute, in the Code there are some expressions that are insufficiently comprehensive and clear. Hence, a number of ambiguous and contentious issues have emerged. Some reach back to the preparatory work on the Code; one such issue is the concept of a party, which-as is well known-is a compromise between the diverse tendencies that clashed within the drafting commission. A number of problems are caused by the rather unfortunate wording of some causes of invalidity (Article 137(1)(1 \& 2). The greatest difficulties, actually quite formidable ones, are posed by the interpretation of the scope of application of the provisions on administrative procedure. All the legislator has said is that the Code "regulates proceedings in individual cases coming within the purview of state administration” (Article 1). It is traditionally believed that the provisions on administrative proce-

55 They include a systematic study (W. Dawidowicz), commentary (E. Iserzon and J. Starościak), monograph (J. Borkowski, Zmiana i uchylenie ostatecznych decyzji administracyjnych, Warszawa 1967), collections of decisions, studies and articles (apart from those quoted above, works by L. Bar, T. Bigo, W. Brzeziński, J. Jendrośka, J. Litwin, J. Służewski) and many other minor but nonetheless valuable contributions.

56 J. Świątkiewicz, H. Starczewski and others.

57 B. Bogomilski, L. Jastrzębski, Z. Młyńczyk, E. Stobiecki, S. Surowiec and others. 
dure only apply to so-called external matters, i.e. when state administration bodies (and the bodies of state organisational units and social organisations, Article 2) perform imperious acts with respect to citizens, legal persons, social organisations and state organisational units located outside these organs; examples include a change of name and surname or a grant of a water permit to a state enterprise, etc. What does not fall within the application scope of the provisions is all kinds of internal matters such as ones related to the operation of state enterprises, service relations and others.

Almost from the very moment the Code came into force, there has been a readily observable tendency to interpret Article 1 broadly. An interesting example of this tendency is a desire to extend the operation of the Code, albeit in part only, to the matters related to the nominated employees of state administration (i.e. persons bound by a service relation, former "officials"). Such tendencies, although they could be charged with contaminating the "purity of theoretic construction", have strong arguments in their favour drawn from life. One such argument is no doubt a desire to extend better legal protection to this category of employees. After all, employees on an employment contract may take advantage of the protection provided by arbitration commissions and, additionally, litigation is open to them, while former officials could avail themselves - if only in part — of the protection provided by administrative courts. Thus, it would be hardly possible to question the position taken on this matter by the CAP Advisory Committee at the Office of Council of Ministers in its well-known opinion. ${ }^{58}$ This opinion could — it seems — serve as grounds for issuing suitable internal regulations adapted to such matters. Anyway, it testifies to the great attractive power of the Code.

58 Opinion no. 12 of the CAP Advisory Committee of 29 April 1963 text with a commentary by L. Jastrzębski, Funkcjonowanie administracji w świetle orzecznictwa, eds. J. Łętowski, J. Starościak, Warszawa 1967, pp. 150 ff. 
An example of other, possibly equally far-reaching tendencies, involves views suggesting the possibility of applying the Code to matters arising in relations between state enterprises and their superior units. ${ }^{59}$

In the entire "Code" period_-if it can be called thus_-beginning with the commencement of the work on the bill, there were demands that a judicial review of administration should be set up. ${ }^{60}$ It is observed that the administrative judiciary could play a role in making administration body decisions uniform, as the Supreme Court does in respect of common courts of law. Moreover the ingenious activity of administrative courts postpones for years the need to amend the Code. Any amendment (at least one made too soon) is rather inadvisable, at least in the case of fundamental legislation, as it could warp the leading lines of legislation. Last but not least, such legislation should be given an opportunity to take root in the popular mind. It is worth remembering here that the judicial review of administration-taking various forms and scopehas become increasingly popular in socialist countries (USSR, Bulgaria, Hungary, Romania and-in a fully-fledged manner-Yugoslavia) ${ }^{61}$

Furthermore, demands have been made on many occasions to set up a commission or some other supra-departmental organ, e.g. at the President of the Council of Minsters or the Office of Council of Ministers, that would take care of the uniformity of administrative decisions. The foundation of such an organ encounters, however, certain difficulties, because of the constitutional powers of the Council of State (Constitu-

59 V. L. Bar, Przedsiębiorstwo państwowe wobec decyzji administracyjnych, "PUG” 1966, no. 8; E. Iserzon, Przedsiębiorstwo państwowe jako strona w postępowaniu administracyjnym, "Państwo i Prawo" 1967, vol. 2; W. Dawidowicz, Kierowanie przedsiębiorstwami państwowymi a kodeks postępowania administracyjnego, "Państwo i Prawo” 1968, vol. 1.

60 Such demands are almost universally made by administrative jurists. Among the representatives of other branches of law, such a demand was made by S. Rozmaryn (cf. the quoted report of a symposium on CAP-related issues in 1961, p. 334 and A. Burda, A. Burda, Demokracja i praworzq̨dność, Wrocław 1965, p. 228.

61 For more information v. J. Starościak, Prawo administracyjne, op.cit., pp. 387 ff.; J, Starościak, Wprowadzenie do prawa administracyjnego..., op.cit., pp. 282 ff., 351; N. Saliszczewa, Administratiwnyj process w SSSR, Moskwa 1964; I. Vintu, Rola sq̨ów powszechnych $w$ dochodzeniu roszczeń spowodowanych bezprawnymi aktami administracyjnymi w SR Rumunii, "Państwo i Prawo” 1968, vol. 2, J. Martonyi, op.cit. 
tion, Article 25(1)(3)). ${ }^{62}$ So far, this role has been fulfilled to an extent by the CAP Advisory Committee at the Office of Council of Ministers. ${ }^{63}$ In the current situation where "ministries and central offices are practically the ultimate interpreters of statutes" ${ }^{\prime 4}$, it is crucial to make their decisions (in particular ones involving precedents) as widely available as possible by publishing them in juristic journals or as freestanding publications. Much of this has already been done in recent years. Special attention is deserved by the publication of collections of decisions with glosses. Pride of place is taken by Orzecznictwo naczelnych organów administracji państwowej published by the General Public Prosecutor's Office in $1964^{65}$, followed by two volumes (the third is forthcoming) of Funkcjonowanie administracji w świetle orzecznictwa published by the Institute of Legal Studies, Polish Academy of Sciences; ${ }^{66} 1969$ saw the publication of Orzecznictwo wodno-prawne by the Central Water Management Board. ${ }^{67}$ Crucial for ensuring the uniformity of decisions, the streamlining of so-called departmental regulations has embarked on its second stage, commenced by the Disposition of the President of the Council of Ministers of $1968 .{ }^{68}$ Reducing the number of all kinds of instructions, circulars, etc. and imposing limits on their "binding force" will certainly have a favourable effect on the administrative decisions of local organs. It must not be forgotten either that advantage

62 V.J. Litwin, Drogi ujednolicenia wykładni prawa administracyjnego, "Państwo i Prawo" 1965, vol. 10, pp. $478 \mathrm{ff}$.

63 Cf. the discussion "CAP in practice" quoted earlier, especially comments by A. Wendel, p. $177 \mathrm{ff}$.

64 J. Starościak, Prawo administracyjne, op.cit., p. 371; J. Litwin, Drogi ujednolicenia wykładni prawa..., op. cit., p. 479.

65 The second volume is edited by H. Starczewski, J. Świątkiewicz, M. Starczewska, B. Czapski and S. Rakowski, Warszawa 1968.

66 Edited by J. Starościak, J. Łętowski in 1967 and 1969.

67 R. Paczuski, I. Centlewska \& E. Górski, eds., Special supplement to Biuletyn Informacyjny, no. 10-11, Bydgoszcz 1969; it gives only a collection of decisions.

68 Disposition no. 14 of the President of the Council of Ministers of 30 January 1968 on the systematisation of departmental regulations and limitation of their number, "GiAT" 1968, no. 4 p. 5 ff. and S. Rozmaryn, Drugi etap prac, “GiAT” 1968, no. 4, p. 7 ff. 
may be taken of the broader powers of public prosecutor's offices conferred upon them by the Act of 14 April 1967.

Finally, matters are improved by the ever-greater professionalism of our administration officials. Almost at the same time as the Code came into force, administration officials began to be trained on administrative courses of study (first vocational, later M.A. programmes) and finally on post-graduate courses. ${ }^{69}$ The curricula of such courses of study, it should be noted, give prominence to lectures on administrative procedure.

\section{Literature}

Angełow A. S., Administratiwnoto proizwodstwo w Czechosłowakia, Ungaria i Polsza, Sofia 1962.

Bar L., Przedsiębiorstwo państwowe wobec decyzji administracyjnych, “PUG” 1966.

Becker F., Das allgemeine Verwaltungsverfahren in Theorie und Gesetzgebung - Eine rechtsvergleichende Untersuchung, StuttgartBruxelles, 1960.

Borkowski J., Zmiana i uchylenie ostatecznych decyzji administracyjnych, Warszawa 1967.

Burda A., Demokracja i praworzq̨dność, Wrocław 1965.

Dawidowicz W., Kierowanie przedsiębiorstwami państwowymi a kodeks postępowania administracyjnego, "Państwo i Prawo” 1968, vol. 1. Filipek J., Stosunek administracyjno-prawny, “Zeszyty Naukowe Uniwersytetu Jagiellońskiego, Prace prawnicze” 1964, vol. 34.

Gellhorn W., Protecting citizens against administrators in Poland, "Revue internationale des sciences administratives” 1964, no. 7,

Iserzon E., Prawo administracyjne. Podstawowe instytucje, Warszawa 1968.

69 Post-graduate Administration Studies are designed for people occupying as a rule a managerial position in administration and holding a degree in other field than law. 
Iserzon E., Przedsiębiorstwo państwowe jako strona w postępowaniu administracyjnym, "Państwo i Prawo” 1967, vol. 2.

Iserzon E., Starościak J. eds, Kodeks postępowania administracyjnego. Komentarz, teksty, wzory i formularze, 3rd ed., Warszawa 1965.

Janowicz Z., Tendencje rozwojowe ustroju administracyjnego Niemieckiej Republiki Federalnej, Poznań 1969.

Jaroszyński M., Zimmermann M., Brzeziński W., Polskie prawo administracyjne. Część ogólna, Warszawa 1956.

Jastrzębski L., Funkcjonowanie administracji w świetle orzecznictwa, eds J. Łętowski, J. Starościak, Warszawa 1967.

Langrod G., La codification de la procédure administrative non contentieuse en Pologne, "La Revue administrative” 1960, no. 6.

Langrod J. S., Uwagi o kodyfikacji postępowania administracyjnego w niektórych państwach, "Państwo i Prawo” 1959, vol. 5-6.

Litwin J., Bibliografia KPA, “GiAT” 1966, no. 4-10.

Litwin J., Drogi ujednolicenia wykładni prawa administracyjnego, "Państwo i Prawo" 1965, vol. 10.

Longchamps F., O pojęciu stosunku procesowego między organem państwa a jednostkq, Księga pamiq̨tkowa dla uczczenia pracy naukowej K. Przybyłowskiego, Kraków-Warszawa 1964.

Meder W., Die Verwaltungsverfahrensordnung der Volksrepublik Polen, "Verwaltungsarchiv" 1961.

Paczuski R., Centlewska I., Górski E. eds, Special supplement to Biuletyn Informacyjny, no. 10-11, Bydgoszcz 1969.

Rozmaryn S., O projekcie kodeksu postępowania administracyjnego, "Państwo i Prawo" 1959, vol. 4.

Rozmaryn S., O zasadach ogólnych kodeksu postępowania administracyjnego, “Państwo i Prawo” 1961, vol. 12.

Rozmaryn S., Principes généraux de la procedure administrative en Pologne, “Deuxièmes Journées Juridiques Polono-Françaises” 1951.

Rozmaryn S., Projekt kodeksu postępowania administracyjnego w nowej postaci”, "Państwo i Prawo” 1960, vol. 4-5. 
Saliszczewa N., Administratiwnyj process w SSSR, Moskwa 1964

Siedlecki W., Kodeks postępowania cywilnego. Komentarz, Warszawa 1969. J. Jendrośka, Zakres obowiq̨zywania k.p.a. w postępowaniach szczególnych, “GiAT”1967, no. 2.

Starościak J., Prawo administracyjne, Warszawa 1965.

Starościak J., Wprowadzenie do prawa administracyjnego europejskich państw socjalistycznych, Warszawa 1968.

Vintu I., Rola sqdów powszechnych $w$ dochodzeniu roszczeń spowodowanych bezprawnymi aktami administracyjnymi w SR Rumunii, "Państwo i Prawo" 1968.

Zimmermann M., Z rozważań nad postępowaniem jurysdykcyjnym i pojęciem strony $w$ kodeksie postępowania administracyjnego, in: Księga pamiq̨tkowa ku czci prof. dr K. Stefki, Wrocław 1967. 